Animal Health Research Institute, Immunity.

\title{
THE EFFECT OF PASTEURELLA MULTOCIDA LIPOPOLYSACCARIDE EXTRACT ON THE IMMUNE RESPONSE OF CHICKENS VACCINATED WITH INACTIVATED NEW CASTLE AND EGG DROP SYNDROME VACCINE
} (With 8 Tables)

\author{
By \\ A.M.E. ASWAY and A.H. MOUSTAFA* \\ *Animal Health Research Institute, Bacteriology \\ (Received at 23/9/2006)
}
تأثير مستخلص الباستريلا ملتوسيدا علي الإستجابة المناعية للاواجن

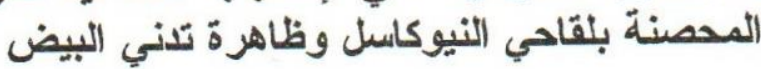

أبو الخبر محمد إيراهيم عيسوي ، عادل هسانبين محمود مصطفي

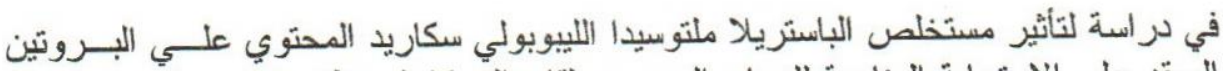

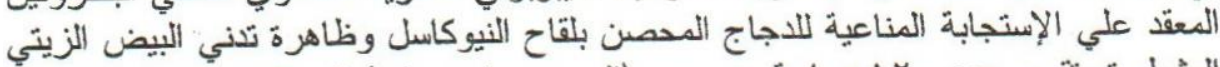

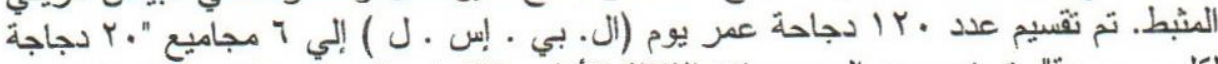

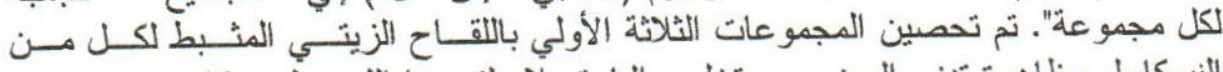

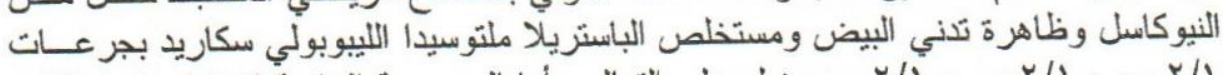

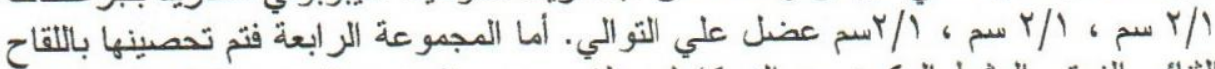

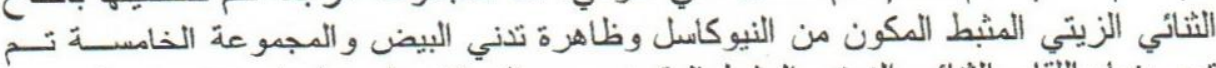

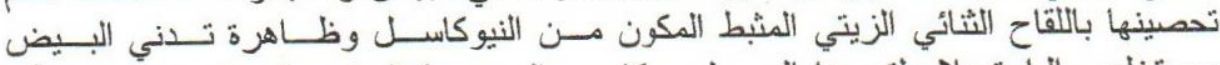

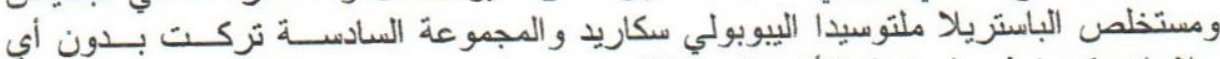

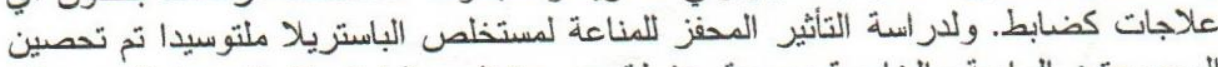

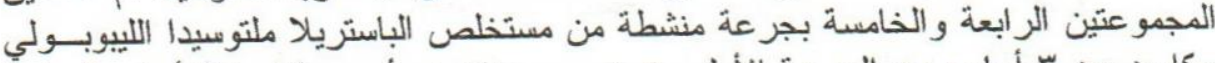

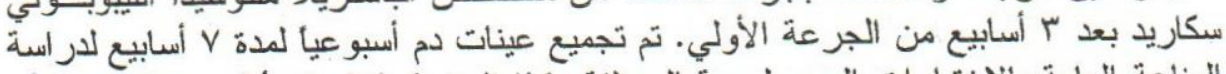

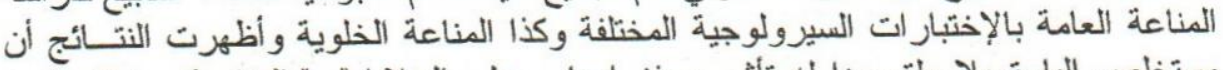

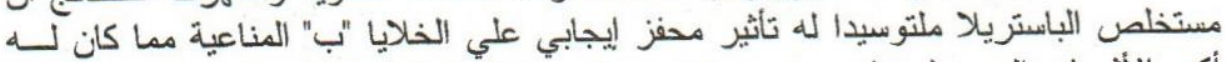

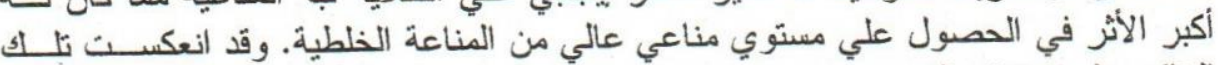

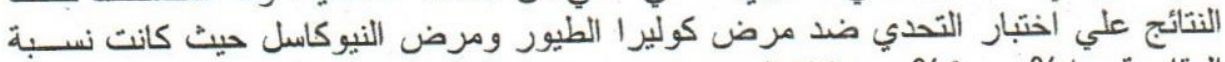

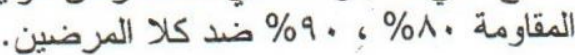




\section{SUMMARY}

A total 120 chickens of L.B.S.L. of one day old were divided into 6 groups "20 chickens for each". The first three groups were vaccinated with oil emulsified inactivated NewCastle "ND", egg drop syndrome "EDS" vaccine and Pasteurella multosida (P.multosida) Lipopolysaccaride extract "LPS" in single doses which are $0.5 \mathrm{ml}, \mathrm{I} / \mathrm{M}$ respectively. The fourth group was vaccinated with bivalent oil adjuvant of ND and EDS. The fifth group was vaccinated with bivalent oil adjuvant vaccine of ND, EDS and LPS. The third and fifth groups received 2 doses of LPS to study its mitogenic effect on the vaccinated chickens. Blood sera were collected till 7 weeks post-vaccination for estimation of cell mediated immunity by lymphocyte transformation, phagocytic activity, phagocytic index and heterophils lymphocytes ratio. Humeral immunity was determined by IHA, HI, ELISA and challenge test. The obtaining data revealed that LPS protein complex of $P$. multocida had a mitogenic effect on chicken B lymphocytes vaccinated with combined NDV and EDS, enhancing the humeral antibodies and the protection against challenge of $P$. multocida and NDV were $80 \%$ and $90 \%$ respectively.

Key words: Pasteurella multocida, New castle, vaccination

\section{INTRODUCTION}

P. multocida has been recognized as an important veterinary pathogen for over a century, it can be either a primary or secondary pathogen in viral disease processes. It is affecting a variety of domestic birds (Rimler and Rhoads, 1987). Viral disease of poultry including NewCastle disease "ND" and egg drop syndrome "EDS" constitute one of the major problems facing the rapidly expanding poultry industry in Egypt causing considerable economic losses (Nadia et al., 2002). EDS is caused by a strain of avian Adenovirus which can be transmitted by the use of contaminated needle used for vaccination or bleeding. Although, it appeared that the virus was transmitted vertically and horizontal transmission between flocks was not feature. The virus remained potent until birds were approaching peak egg production (Saif et al., 2004).

The economic importances of these viral diseases are manifested by clinical disease and high mortality rate as well as the severe prolonged immunosuppressive effect on the infected chickens. This enhanced of the bacterial pathogen $P$. multocida to flourish up and 
induced its fatal disease (Nadia et al., 2002). Inactivated NDV vaccine was given I/M induced little resistance and the neutralizing antibodies may not be sufficient to protect against disease (Reynolds and Maraqa, 2000).

The role of cell mediated immunity in protection from ND by itself was not protective against a virulent NDV challenge, antibodies directed against surface glycoprotein or polypeptides of NDV have been reported to inactivated and neutralize the free virus and play the major role in its immmunogenicity and protection of chickens against the virulent infection with ND (Reynolds and Maraqa, 2000). Lipopolysaccharide of $P$. multocida is a phenotypic antigen which provides protection against heterologous serotypes. The polysaccharide component of LPS has been identified as the major role in adherence of capsular serotype "D" of $P$. multocida to avian epithelial cells (Coy et al., 1997).

Some Gram-negative bacteria are able to vary the composition of lipopolysaccharide on their outer surface in order to evade host defenses or increase bacterial virulence (Chrishodgson, 2002). LPS is a factor in Gram-negative bacterial infection that can potentially enhance the inflammatory response during bacterial infection, enhances metabolic activity, phagocytic function and it is a mitogenic for lymphocytes (Confer and Simons, 1986).

The immunological reactivity of LPS isolated from potassium thiocyanate extract of $P$. multocida capsular type A provided $100 \%$ protection against challenge with homologous strain and this component is a mitogenic for mice B-lymphocytes, induction of delayed type of hypersensitivity and humoral immunity (RyuHyol and Kim Chufjoong, 2000).

The aim of this work was planned to study the effect of $P$. multocida lipopolysaccharide extract "LPS" on chicken immune response vaccinated with oil adjuvant inactivated vaccine against NDV and EDS.

\section{MATERIALS and METHODS}

\section{Strains:}

\section{Bacterial strains:}

P. multocida standard strains serotypes 5:A, 8:A, 9:A and $\mathrm{D}_{2}$ were supplied by Vet. Serum and Vaccine Research Institute, Abbasia, Cairo. 


\section{Virus strains:}

(1) New Castle disease virus:

a) Velogenic strain of NDV "the titre was $10^{6} \mathrm{EID}_{50}$ " used for challenge was supplied by Vet. Serum and Vaccine Research Institute, Abbasia, Cairo.

b) Lasota strain; the titre of the virus was $10^{6} \mathrm{EID}_{50} / \mathrm{ml}$ was supplied by IZO S.P.A. Brescia-Italy.

c) Inactivated oil adjuvant NDV vaccine, $50 \mathrm{PD}_{50}$ was supplied by IZO S.P.A. Brescia-Italy.

(2) Inactivated oil adjuvant EDS vaccine, EDS-76:10 ${ }^{8}$ EID $_{50}$,

Was supplied by IZO S.P.A. Brescia-Italy.

(3) Inactivated oil adjuvant against ND and EDS-76:

Brescia-Italy.

NDV:50 $\mathrm{PD}_{50}$ and EDS-76:10 ${ }^{8} \mathrm{EI}_{50}$ was supplied by IZO S.P.A.

\section{Chickens:}

A total of 120 chickens of one day old of L.B.S.L. or heavy breeders (United Company for Poultry Production" were reared under complete hygienic measurements in isolated and disinfected wire floored cages, commercial broiler ration was used.

\section{Rabbits:}

A total of 8 Boscat rabbits from $1-1.5 \mathrm{~kg}$ were used for passage of $P$. multocida strains.

\section{Mice:}

A total of 10 Swiss Albino mice about 15-20 gm weight were used for measurement the toxicity of the prepared LPS of $P$. multocida as mentioned by Rebers and Rimler, (1984).

Preparation of P. multocida lipopolysaccharide extract "LPS":

Formalized LPS of protein complex of P. multocida capsular type "A" and "D" somatic type '3" and "11" was prepared as described by Avakian et al., (1985).

Equal amount of formalized ND-EDS and LPS were mixed thoroughly with oil adjuvant as described by Abou El-Khair and Eman, (1999).

Evaluation of cell mediated immunity:

(1) Estimation of lymphocyte blastogenes:

Using tetrazolium calorimetric assay according to Mosmann, (1983). Results of test were expressed as delta optical density.

$A O D=(O D$ of PHA $-O D$ of media $)-O D$ of cell- OD of media 
(2) Macrophage activity test:

This test was carried out according to Barry and Elisson., (1988) and modified by El-Enbawy (1990).

$$
\text { Phagocytic percentage }=\frac{\text { No. of phagocyte which ingest Candida }}{\text { Total No. of phagocytes }} \times 100
$$

\section{(3) Determination of phagocytic index:}

The phagocytic index was carried out according to Richardson and Smith, (1981) and modified by El-Enbawy, (1990).

Phagocytic index. ${ }^{\text {Total No. of phagocyte which ingest more than two Candida }}$ X 100

Total No. of phagocytes which ingest Candida

(4) Determination of heterophil/lymphocyte ratio:

The test was done according to Gross and Siegel, (1983).

Evaluation of the humoral immunity:

(1) Indirect haemoagglutination inhibition test:

This test was used to determine the antibody titres against P. multocida LPS as mentioned by Carter, (1972).

\section{(2) Haemoagglutination inhibition test:}

This test was carried out to detect the antibodies against NDV according to Majujabe and Hitchner, (1977) and to detect the antibody assay against Adenovirus using micro-method of Takatsy, (1956) using virus suspension containing $4 \mathrm{HA}$ units.

Enzyme linked immunosorbent assay (ELISA):

It was carried out according to Briggs and Skeels, (1984).

\section{Challenge test:}

10 chickens of the 4 vaccinated groups ND, LPS, LPS + ND + EDS and control group were challenged with the virulent strains of P. multocida "A", "D" $0.5 \mathrm{ml} \mathrm{I} / \mathrm{M}$ of $1.2 \times 10^{5} \mathrm{cFu}$ as described by Abou El-Khair and Eman, (1999).

10 chickens of these groups were challenged with velogenic strain of NDV $0.5 \mathrm{ml}$ containing $10^{6} \mathrm{EID}_{50}$. These chickens were observed for 15 days as mentioned by Nadia et al., (2002). 
Table 5: Antibody titres against $P$. multocida type "D" and "A" in the immune potentiated in the ND and EDS vaccinated chicken with $P$. multocida LPS by IHA

\begin{tabular}{|c|c|c|c|c|c|c|c|c|}
\hline \multirow{3}{*}{ Vaccinated group } & \multicolumn{7}{|c|}{ Intervals of blood collection post vaccination/week } & \multirow{3}{*}{$\begin{array}{c}\text { Overall } \\
\text { mean }\end{array}$} \\
\hline & \multicolumn{3}{|c|}{ Primary vaccination } & \multicolumn{4}{|c|}{ Booster vaccination } & \\
\hline & $\begin{array}{c}1^{\text {st }} \\
\text { week }\end{array}$ & $\begin{array}{c}2^{\text {nd }} \\
\text { week }\end{array}$ & $\begin{array}{c}3^{\text {rd }} \\
\text { week }\end{array}$ & $\begin{array}{c}4^{\text {th }} \\
\text { week }\end{array}$ & $\begin{array}{c}5^{\text {th }} \\
\text { week }\end{array}$ & $\begin{array}{c}6^{\text {th }} \\
\text { week }\end{array}$ & $\begin{array}{c}7^{\text {th }} \\
\text { week }\end{array}$ & \\
\hline \multicolumn{9}{|l|}{ LPS: } \\
\hline Type "D" & 7 & 60 & 252 & 511 & 62 & 118 & 115 & 161 \\
\hline Type "A" & 30 & 124 & 511 & 511 & 509 & 291 & 256 & 319 \\
\hline \multicolumn{9}{|l|}{ LPS+EDS +ND: } \\
\hline Type "D" & 8 & 30 & 251 & 1022 & 515 & 1023 & 512 & 480 \\
\hline Type "A" & 61 & 64 & 510 & 512 & 512 & 1022 & 1022 & 529 \\
\hline \multicolumn{9}{|l|}{ Control: } \\
\hline Type "D" & 8 & 4 & 2 & 5 & 7 & 8 & 4 & 5 \\
\hline Type "A" & 4 & 2 & 2 & 4 & 2 & 2 & 3 & 3 \\
\hline
\end{tabular}

Table 6: Geometric mean of $\log _{2} \mathrm{HI}$ antibody titre against ND and EDS in the immune potentiated vaccinated chicken with $P$.
multocida LPS

\begin{tabular}{|c|c|c|c|c|c|c|c|c|}
\hline \multirow{3}{*}{ Vaccinated group } & \multicolumn{7}{|c|}{ Intervals of blood collection post vaccination/week } & \multirow{3}{*}{$\begin{array}{c}\text { Overall } \\
\text { mean }\end{array}$} \\
\hline & \multicolumn{3}{|c|}{ Primary vaccination } & \multicolumn{4}{|c|}{ Booster vaccination } & \\
\hline & $\begin{array}{c}1^{\text {st }} \\
\text { week }\end{array}$ & $\begin{array}{c}2^{\text {nd }} \\
\text { week }\end{array}$ & $\begin{array}{c}3^{\text {rd }} \\
\text { week }\end{array}$ & $\begin{array}{c}4^{\text {th }} \\
\text { week }\end{array}$ & $\begin{array}{c}5^{\text {th }} \\
\text { week }\end{array}$ & $\begin{array}{c}6^{\text {th }} \\
\text { week }\end{array}$ & $\begin{array}{c}7^{\text {th }} \\
\text { week }\end{array}$ & \\
\hline EDS+ND: & 7.70 & 7.92 & 9.92 & 7.67 & 7.80 & 7.30 & 7.80 & 8.02 \\
\hline \multicolumn{9}{|l|}{ EDS+ND+LPS: } \\
\hline Single & 7.00 & 7.80 & 8.45 & 9.33 & 7.65 & 7.50 & 7.00 & 7.82 \\
\hline Double & 9.00 & 9.90 & 9.50 & 8.55 & 9.75 & 8.60 & 8.42 & 9.10 \\
\hline ND: & 6.00 & 6.20 & 8.30 & 8.00 & 6.00 & 6.40 & 7.30 & 6.88 \\
\hline EDS: & 8.00 & 10.30 & 9.10 & 8.75 & 7.55 & 7.00 & 7.00 & 8.24 \\
\hline \multicolumn{9}{|l|}{ Control: } \\
\hline ND & 0 & 0 & 0 & 0 & 0 & 0 & 0 & 0 \\
\hline EDS & 0 & 0 & 0 & 0 & 0 & 0 & 0 & 0 \\
\hline
\end{tabular}

Single: chicken groups received one dose of combined EDS + ND + LPS

Double: chicken groups received 2 doses of combined EDS + ND + LPS 
Table 7: Challenge against $P$. multocida serotype "A" and "D"

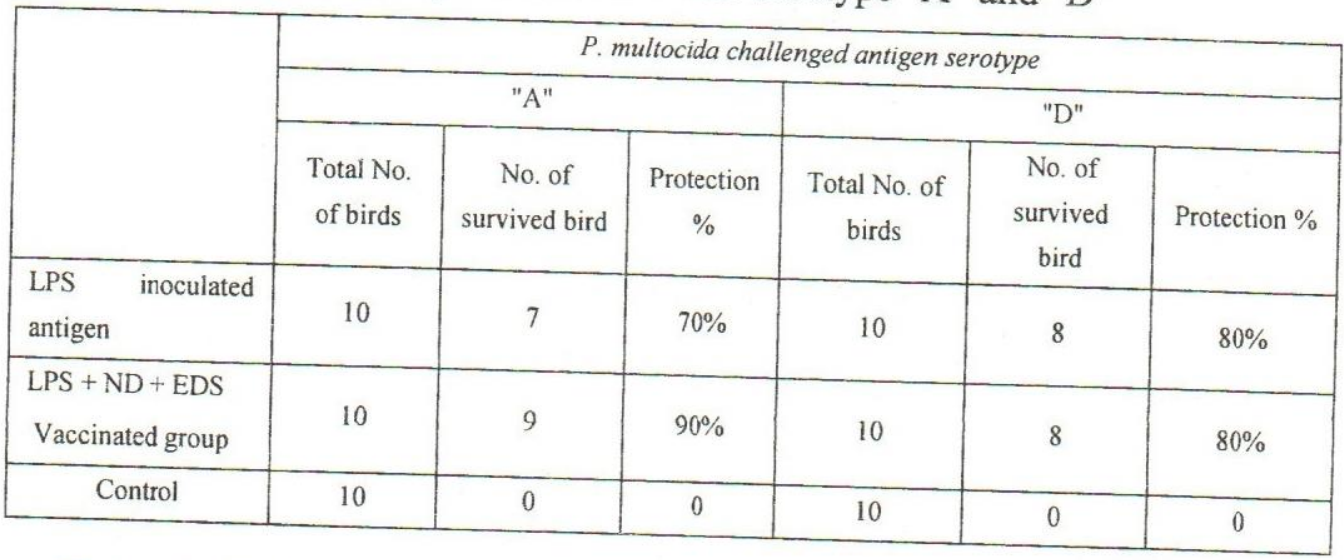

Table 8: Challenge against ND

\begin{tabular}{|l|c|c|c|}
\hline \multirow{2}{*}{} & \multicolumn{3}{|c|}{ ND challenged antigen } \\
\cline { 2 - 4 } & Total No. of birds & No. of survived birds & Protection \% \\
\hline EDS + ND & 10 & 7 & $70 \%$ \\
\hline EDS + ND + LPS & 10 & 9 & $90 \%$ \\
\hline ND & 10 & 8 & $80 \%$ \\
\hline \multicolumn{1}{|c}{ Control } & 10 & 1 & $10 \%$ \\
\hline
\end{tabular}

\section{DISCUSSION}

ND and Adenovirus have caused resemble non-pathogenic respiratory lesions. The immunosuppressive effect of these viruses on chickens industry was complicated by bacterial invader as $P$. multocida and E. coli (Dhillan and Kilbenge., 1987). New strategies are urgently required to solve this problem; mass vaccination must be used in commercial poultry industry to increase the effectiveness of live and inactivated viral vaccines by adding different additives known to be immunostimulant (Tolba et al., 2000). This study was planned to monitor the mitogenic effect of $P$. multocida lipopolysaccharide complex on cellular and humoral immune response of chickens vaccinated with a combined LPS, ND, EDS vaccine throughout 7 weeks. Concerning the cell mediated immunity as estimated by lymphocytic blastogensis in Table (1) revealed that the highest lymphocyte transformation was in a period from $2^{\text {nd }}$ to $3^{\text {rd }}$ week post primary vaccination. There was descending lymphocytic blastogenesis in the 
vaccinated chickens were in combined ND, EDS, LPS, then monovalent LPS, ND and EDS lastly combined EDS and ND as follows 0.066 , $0.056,0.54$ and 0.042 respectively in compared with the control group was 0.022 . These findings were supported by Reynolds and Maraqa, (2000) who used the lipopolysaccharide from Salmonella typhimurium as the B. cell mitogen for the whole blood blastogenesis microassay to enhance the cell mediate immune response of chicken vaccinated with different types of NDV inactivated vaccine.

Ryu Hyol and Kim Chufjoong (2000) found that LPS protein complex of $P$. multocida induced cell mediated immunity in mice by mitogenic responses of $\mathrm{T}$ and B-lymphocytes.

The cell mediated microassay was confirmed by macrophage activity as expressed by phagocytic percentage, the phagocytic index by using Candida albocans as well as estimation of heterophils lymphocytes ratio "H/L ratio" as illustrated in Tables (2, 3 and 4). These tabulated data revealed that LPS protein complex of $P$. multocida or combined with ND and EDS inactivated vaccine induced maximum cellular immunity was detected two weeks post primary vaccination. The highest overall mean of the phagocytic activity in the combined vaccinated chicken with LPS, ND and EDS then LPS 69.32\%, 59.18\% respectively when compared with no noticeable difference in the monovalent ND, EDS and combined ND and EDS vaccinated groups, which were $38.44 \%, 34.56 \%$ and $33.32 \%$ respectively.

These findings were similar to the results of the phagocytic activity induced by Candida albicans expressed by phagocytic index as well as the result of cellular immunity determinated by heterophils lymphocyte ratio tabulated in Table (4). The maximum immunostimulation effect of $P$. multocida LPS (H/L ratio) was detected by the least $\mathrm{H} / \mathrm{L}$ ratio in the combined vaccinated ND, EDS, LPS and LPS $0.21,0.37$ then followed by the lower cellular immune response of the vaccinated chicken groups with EDS, EDS + ND and lastly ND were as follows $1.27,1.05$ and 1.31 respectively. These data were in agreement with by Vanden Hurk, (1990), as reported that Adenovirus production in chicken lymphoid cells, monocytes macrophage and Blymphocytes required cell actively engaged in DNA and protein synthesis because higher virus yields were obtain in lymphocytes after stimulation with $\mathrm{T}$ and B-lymphocytes mitogens phytohemoagglutinin and LPS concerning with the humoral immune response.

There was a noticeable elevation in the overall mean of antibodies titres against $P$. multocida type $\mathrm{A}$ and $\mathrm{D}$ by indirect 
haemagglutination as tabulated in Table (6) as mentioned by Coy et al., (1997) that the polysaccharide components of LPS has been identified as the major adhesion in attachment in a member of family Pasteurellaceae to the avian epithelium cells of trachea. A LPS protein complex of $P$. multocida is postulated to induce specific immunity to the extent that the antibodies directed against LPS are associated with protection against infection. Geometric mean titre and the overall mean titre against ND and EDS as determined by haeagglutination inhibition and ELISA as in Table (6) were slightly devoted in the combined vaccinated group with LPS, ND and EDS than single vaccinated group with EDS or ND. The double doses of LPS of P. multocida potentiated the antibodies induction against $P$. multocida, NDV and EDSV in the group of chicken vaccinated with a combined LPS, ND and EDS.

These data agreed with Sasaki et al., (1969) mentioned that the antibody titres of the combined inactivated viruses and inactivated bacteria never inferior to the titres obtained with separate single vaccine. Also, Meferran et al., (1975) stated that the single I/M injection of inactivated Adenovirus with adjuvant developed good response and highest titres of antibodies reach to peak titres in 3 to 4 weeks and the response is long lasting.

The interpretation of the findings evaluated in Table (7) the protection against virulent chaneng of P.multocida were $90 \%, 80 \%$ for the vaccinated chickens with either combined LPS, NDV and EDS or LPS respectively, these data agreed with Rimler et al., (1984). They mentioned that haptenic and immunogenic property of a particular LPS in probably related to its chemical composition as well as its structure and its chemical analysis had shown that LPS from $P$. multocida contain lipid A and some polysaccharides, so the antibodies against purified LPS of $P$. multocida avian strain, protected chicken against challenge with the homologous organism.

The results illustrated in Table (8) revealed the best satisfied protection of the vaccinated chicken against the challenge with virulent strain of NDV in the groups of chicken vaccinated with combined ND, EDS and LPS followed by ND then combined ND and EDS were $90 \%$, $80 \%$ and $70 \%$ respectively, when compared with $10 \%$ in the control group.

This interpretation from these results of this study is that antibodies are key components for protective immunity to ND. This interpretation might be considered contradictory to reports that have emphasized the importance of cell-mediated immunity stimulated by B- 
lymphocytes mitogen as LPS of Gram negative bacteria is containing lipids " $\mathrm{A}$ " is acting as a key component in protection against ND viral infection as well as the cytotoxic cell activity in preventing further spread of the virus and terminating infection (Reynold and Maraqa, 1999).

The conclusion of these findings was the combination of P. multocida lipopolysaccharide complex with inactivated ND and EDS vaccine revealed a satisfactory mitogenic response of B-lymphocytes, enhanced the cellular and humoral immunity of the vaccinated chicken as well as enhanced the protection against the virulent challenge against P. multocida NDV and EDSV. Also, there was no interference between bacterial and viral inactivated antigens on the immune response of the vaccinated chicken with these multi-antigens.

\section{REFERENCES}

Abou El-Khair, M.A. and Eman, M.E. (1999): Trials for preparation of a combined inactivated Reovirus and fowl cholera vaccine. J. Egypt. Vet. Med. Ass., 59 (2): 1105-1120.

Avakian, A.P.; Dick, J.W.; Derieux, W.T. and Henry, C.W. (1985): Comparison of various antigens and their ability to detect protective antibodies against $P$. multocida using enzyme linked immunosorbent assay. Avian Dis., 30 (3): 527-523.

Barry, Gh.J.R. and Elisson (1988): Activity of avian peritoneal macrophages. Avian Dis., 33: 177-181.

Briggs, D.I. and Skeels, J.K. (1984): As enzyme linked immunosorbent assay for detecting antibodies to $P$. multocida in chicken. Avian Dis., 28 (1): 208-218.

Carter, G.R. (1972): Improved haemagglutination test for identifying type A strain of P. multocida. Appl. Microbiol., 29: 162-13.

Chrishodgsen, (2000): Lipopolysaccharide chemotypes of $P$. haemolytica. http:/www. mri.ac U.K./bacteriology/lipo. Htm 2002/2/7. Page 1 of 2, page 2 of 2 .

Confer, A.W. and Simons, K.R. (1986): Effects of P. haemolytica lipopolysaccharide on selected function of bovine leukocytes. Am. J. Vet. Res., 47 (1): 154-157.

Coy, S.L.; Lee and sander, I. (1997): Inrastrain variation of lipopolysaccharide of P. multocida in turkeys. Am. J. Vet. Res., 58 (7): 755-759. 
Dhilion, A.S. and Kibenge, F.S.B. (1987): Adenovirus infection associated with respiratory disease in commercial chickens. Avian Dis., 31: 654-657.

El-Enbawy, M.I. (1990): Some studies on Candida albicans. Ph.D. Thesis (Microbiology), Fac. Vet. Med., Cairo University.

Gross, W.B. and Siegel, H.S. (1983): Evaluation of (Heterophils/lymphocyte) ratio as measure of stress in chicken. Avian Dis., 27 (4): 927-979.

Majujabe, K.A. and Hitchner, S.B. (1977): Antibody response to strain combination of NewCastle disease virus as measured by haemagglutination inhibition test. Avian Dis., 21: 576-584.

Meferran, J.B.; Adair, B.Bsc. and Connor, T.J. (1975): Adenovirus antigens "CELO, QBV, GAL". Am. J. Vet. Res., 36 (4): $527-$ 529.

Mosmann, T. (1983): Rapid calorimetric assay for cellular growth and cytotoxicity assays. J. Immunol. Meth., 65: 55.

Nadia, M.H.; Mohamed, A.A.; Ensaf, H.Kh.; Salwa, A.E.; Fekria, A.El. and Afaf, H.A. (2002): Trials for preparation of oil emulsion tetravalent vaccine against NewCastle, egg drop syndrome, Reo virus and Infectious bursal disease. Suez Canal Vet. Med. J., 2: 681-690.

Rebers, A.P. and Rimler, B.R. (1984): The effect of formalin killing of $P$. multocida on the antigenicity and extractability of the lipopolysaccharide. Carbohydrate Research. 133: 83-94.

Reynolds, D.L. and Maraqa (1999): A rapid virus neutralization assay for New Castle disease virus using the swine testicular continuous disease cell line. Avian Dis., 43: 564-571.

Reynolds, D.L. and Maraqa (2000): Protective immunity against New

Castle disease: the role of cell mediated immunity. Avian Dis., 44: 145-154.

Reynolds, D.L. and Maraqa (2000): Protective immunity against New Castle disease: the role of disease antibodies specific to NewCastle disease virus lipopeptide. Avian Dis., 44: 138-144.

Richardson, M.D. and Smith, H. (1981): Resistance of virulent and attenuated strain of Candida albicans to intracellular killing human and mouse phagocytes. J. Infect. Dis., 144: 557-565.

Rimler, R.B. and Rhoades, K.R. (1987): Pasteurella multocida. J. Clin. Microbiol., 25: 615-618.

Rimler, R.B.; Rebers, P.A. and Phillips, M. (1984): Am. J. Vet. Res., 45: 759-763. 
Ryu Hyol and Kim Chufjoong (2000): Immunologic reactivity of a lipopolysaccharide protein complex of type A P. multocida in mice. J. of Vet. Sci., 1 (2): 87-95.

Saif, Y.M.; Calnek, B.W.; Barnes, J.H.; Charles, W.B. and Larry, R.M. (2004): Egg drop syndrome. Disease of Poultry, $11^{\text {th }}$ Ed., 633642.

Sasak, N.T.; Herahara and Isumida, A.A. (1969): Application to comparative studies of vaccination against NewCastle (ND), avian infectious bronchitis (IB) and avian infectious laryngeotrachitis (ILT). 1- som observations on several combinative vaccine and occasionally with vaccination. Jap. J.
Vet. Sci., 31 .

Takasty, H. (1956): IB,effect of viral doses in chickens. Avin Dis ., 41 (2): $379-387$.

Tolba, S.K.; Abozeid, A.A.; Abdel-Wanis, N.A. and Madkour, M.S. (2000): Trials to improve the immune response of live NewCastle disease vaccine. J. Vet. Med. Res., 2 (1): 37-81.

Vanden Hurk, J.V. (1990): Propagation of group II avian Adenovirus in turkey and chicken leukocyte. Avian Dis., 34: 12-25. 